
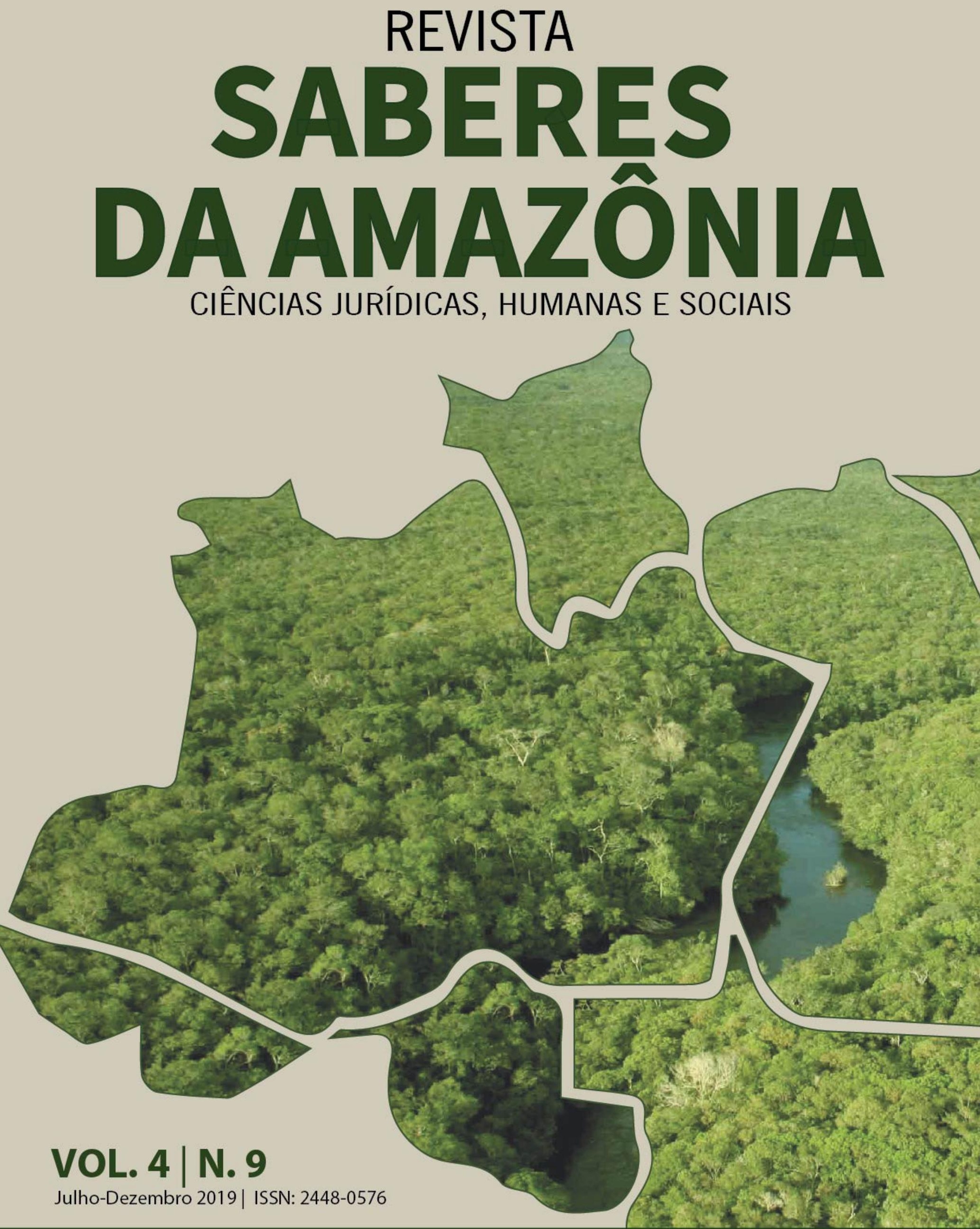


\title{
A CRIMINALIZAÇÃO DA LÓGICA ECONÔMICA INDÍGENA NO USO DE CARTÕES DE BENEFÍCIOS SOCIAIS
}

\section{THE CRIMINALIZATION OF INDIGENOUS ECONOMIC LOGIC IN THE USE OF SOCIAL BENEFIT CARDS}

\begin{abstract}
Daniel Luis Dalberto ${ }^{1}$ Julio César de Aguiar ${ }^{2}$

Os povos sem escrita não são então menos adultos que as sociedades letradas. Sua história é tão profunda quanto à nossa e, a não ser por racismo, não há por que julgá-los incapazes de refletir sobre a sua própria experiência e de dar a seus problemas as soluções apropriadas ${ }^{3}$.
\end{abstract}

\section{Resumo}

Em Guajará-Mirim, região amazônica que possui grande diversidade étnica, na última década houve significativo incremento de concessão de benefícios sociais aos índios, implementados sem observância às especificidades de populações socioculturalmente diferenciadas, o que, somado às características da região, moldou um sistema próprio de comércio, consistente na retenção de cartões bancários e outorga de procurações pelos índios aos comerciantes com quem negociam. Tais relações foram e tem sido tratadas pelo Estado como crime de estelionato contra os indígenas. Este artigo, a partir de relato de caso concreto, analisa a natureza dessas relações, considerando as perspectivas de cada ator, levando em conta os aspectos históricos, geográficos, econômicos e antropológicos, concluindo pelo equívoco da criminalização da relação objeto do estudo, que replica antigos preconceitos e estereótipos, sendo insuficiente o enfoque do Direito Penal para compreensão e enfrentamento do problema.

\section{Abstract}

In Guajará-Mirim, an Amazon region that has great ethnic diversity, over the last decade there has been a significant increase in the granting of social benefits to the Indians, implemented without regard to the specificities of socio-culturally

\footnotetext{
1 Mestrando em Direito pela Universidade Católica de Brasília. Especialista em Direito Público pela Universidade Anhanguera-Uniderp. Procurador da República.

$2 \mathrm{PhD}$ in Law pela University of Aberdeen, Reino Unido. Doutor em Direito pela Universidade Federal de Santa Catarina. Mestre em Filosofia pela Universidade Federal de Goiás.

3 CLASTRES, Pierre. A sociedade contra o Estado: pesquisas de antropologia política; tradução de Theo Santiago. Rio de Janeiro, F. Alves, 1978. Pág. 16.
} 
differentiated populations, in addition to specific characteristics of the region, shaped an own trading system, consisting in the retention of bank cards and the granting of proxies by the Indians to the traders with whom they trade. Such relations were and have been treated by the State as a crime against the Indians. This article, based on the concrete case study, analyzes the nature of these relations, considering the perspectives of each actor, taking into account the historical, geographical, economic and anthropological aspects, concluding by the misconception of the relation object of the study criminalization, which replicates old prejudices and stereotypes, being insufficient the approach of the Criminal Law to understand and confront the issue.

\section{INTRODUÇÃO}

A Constituição de 1988, em alinhamento a normas internacionais desenvolvidas a partir de meados do século $X X$, inaugurou marco jurídico que mudou a histórica tentativa de assimilação e inserção dos índios na sociedade nacional, reconhecendo às populações nativas sua organização social, costumes, línguas, crenças e tradições ${ }^{4}$, exigindo, como direito fundamental, que as políticas públicas tenham a participação dos povos indígenas em todas as fases.

Esse contexto normativo ainda não é aplicado no mundo dos fatos e o Programa Bolsa Família - PBF é implementado de modo massificado e, dessa maneira, impacta significativa parcela da população indígena da Região de Guajará-Mirim, Estado de Rondônia, na fronteira do Brasil com a Bolívia.

Consequência da inadequação e ineficiência da política pública, nessa região consolidou-se um modo de comércio entre índios e comerciantes, que tem sido criminalizado como estelionato.

A complexidade que costumeiramente envolve a interculturalidade, ainda mais numa região que é um mosaico de culturas indígenas, as dificuldades de transporte às aldeias, cujo acesso se dá basicamente por rios, a muitas horas e, às vezes, a dias de viagem, a depender da estação do ano, o fato de uma parte das supostas vítimas ser de índios idosos, que tiveram contato com a sociedade envolvente já em idade adulta, ou de índios com pouca compreensão da língua portuguesa e do nosso sistema monetário e mercantil,

4 Artigo 231 da Constituição da República. 
indicaram que a compreensão do caso poderia extrapolar as aparências iniciais de abuso em relação consumerista ou de crime de estelionato.

O artigo fará relato do caso, analisando os principais fatos ocorridos nos inquéritos policiais, processos penais e inquérito civil, considerando as visões de cada ator envolvido, para compreender a lógica econômica e antropológica que permeia as relações estudadas. Verificaremos, ao final, se de fato houve tipicidade das condutas e se há adequação do modo como o Estado tem implementando o PBF para as populações indígenas envolvidas.

\section{DOS FATOS OCORRIDOS E APURADOS NOS INQUÉRITOS POLICIAIS E NAS INSTRUÇÕES PROCESSUAIS}

Os processos ${ }^{5}$ foram antecedidos por inquéritos policiais ${ }^{6}$, instaurados a partir de prisão em flagrante de comerciante que estava na sala de atendimento da Caixa Econômica Federal de Guajará-Mirim na posse de 21 cartões bancários de indígenas. A partir desse fato, as investigações evoluíram e o Delegado da Polícia Federal representou pela medida cautelar de busca e apreensão no estabelecimento e na casa de outro comerciante.

A Polícia Federal investigou no Cartório de Notas da Comarca de Guajará-Mirim e apurou que um dos comerciantes investigados detinha mais de 300 procurações de indígenas de diversas etnias. Por ocasião do cumprimento do mandado judicial de busca e apreensão, o segundo comerciante foi preso em flagrante. Além dos cartões, procurações e notas promissórias, foi encontrada uma carteira de identidade e 08 certidões de nascimento de índios. Também, diversos extratos bancários e cadernos com anotações manuais de produtos entregues e a entregar. Relevante referir que entre as supostas vítimas havia professores, servidores indígenas do Ministério da Saúde e um índio servidor da Funai.

A seguir, esse comerciante de Guajará-Mirim, dono de mercado que vende produtos de necessidades básicas, como alimentos e roupas, foi 
denunciado pelo MPF por ter praticado 92 estelionatos $^{7}$ e ter retido um cartão magnético de idoso. Dos 92 cartões apreendidos em seu poder, 89 eram de indígenas, sendo 61 vinculados a contas corrente ou poupança, 19 utilizados para recebimento de benefícios previdenciários, 09 utilizados para 0 recebimento de benefícios assistenciais, em especial, o bolsa-família.

O comerciante tinha em sua posse dezenas de procurações outorgadas por indígenas, com amplos poderes para movimentar suas contas e para fazer empréstimos em seus nomes. Possuía, também, inúmeras notas promissórias assinadas pelos índios, sem que houvesse, em sua maioria, qualquer especificação do valor ou da causa que as justificasse. Foram apreendidos documentos relativos a financiamentos bancários em nome dos índios, cadernos de anotações de compras, sem especificações detalhadas sobre quantidades e preços.

No mesmo mês e ano, o primeiro comerciante que havia sido preso em flagrante também foi denunciado. Dentre os 21 cartões que detinha quando foi preso, 4 pertenciam a idosos. Possuía, também, dezenas de procurações com amplos poderes para movimentar contas bancárias dos indígenas, inclusive para fazer empréstimos bancários em seus nomes.

As denúncias criminais são muito parecidas. Uma delas descreve o método praticado da seguinte forma:

[...] os indígenas vão até o mercado ou mandam um pedido por escrito; o denunciado entrega os produtos, sem informar o preço; todas as vendas são "registradas", sem discriminação de produtos e/ou preços e por valores totais, em "cadernos"; assim, todos os indígenas criam débitos com o denunciado. Os preços praticados são abusivos, bem superiores aos praticados na localidade. De posse dos cartões magnéticos, procurações e etc., o denunciado vai ao Banco e realiza saques ou transferências bancárias (o denunciado como favorecido), quando e no valor que bem entender. Ao fim do mês (ou outro período, a depender do caso), presta contas aos indígenas, que, invariavelmente, nada tem a receber e muito devem (emblemático o relato de fls. 47), nada obstante pouco tenham adquirido no mercado. Desta forma, os indígenas vitimizados ficam dependentes do denunciado. Todo o valor que recebem fica em posse deste. Os indígenas sempre estão devendo, já que a "contabilidade" é

7 Art. 171 do Código Penal - Obter, para si ou para outrem, vantagem ilícita, em prejuízo alheio, induzindo ou mantendo alguém em erro, mediante artifício, ardil, ou qualquer outro meio fraudulento:

Pena - reclusão, de um a cinco anos, e multa, de quinhentos mil réis a dez contos de réis. 
fantasiosa. Em todos os depoimentos de fls. 42-50, foi afirmado a completa falta de consciência quanto ao montante da conta, bem como sua correspondência com a realidade. Veem seu poder aquisitivo diluído, já que os preços são abusivos [...].

O crime de estelionato exige obtenção de vantagem ilícita, obtida, de acordo com a acusação, tanto pelo valor abusivo das mercadorias como pela contabilidade fraudulenta e vaga, dando ao denunciado a possibilidade de registrar o que bem entendesse. O prejuízo alheio, outra elementar do crime, teria sido caracterizado pelos preços abusivos e pela cobrança de dívidas inexistentes. A utilização de meio fraudulento para indução dos índios em erro teria sido a completa ausência de discriminação de preços e as fraudes na contabilidade. $\mathrm{O}$ outro delito denunciado foi a retenção de cartão de benefícios previdenciários de idosos. ${ }^{8}$

Nas denúncias, os índios foram arrolados como vítimas. A Justiça entendeu por intimá-los como testemunhas, mas acabou ouvindo-os como vítimas, salvo os índios arrolados como testemunhas de defesa, que foram então compromissados a falar a verdade, já que testemunhas em processo judicial têm essa obrigação, sob pena de cometer crime de falso testemunho.

O comerciante que sofreu o mandado de busca e apreensão, após ter sido preso em flagrante, pediu a liberdade provisória. O MPF pugnou pela manutenção de sua prisão, com a conversão em prisão preventiva. O Juiz Federal decidiu determinar a prisão preventiva do comerciante, dada a quantidade de vítimas, segundo ele - evidentemente hipossuficientes por serem indígenas e idosos - e considerou que havia muitos anos o denunciado estava a praticar crimes, o que indicava habitualidade. Cerca de vinte dias após, o Tribunal Regional Federal da $1^{\text {a }}$ Região -TRF1, com sede em Brasília, em Habeas Corpus $^{9}$, deu ordem de soltura do comerciante, fixando outras medidas cautelares diversas.

8 Art. 104 da Lei 10.741/03. Reter o cartão magnético de conta bancária relativa a benefícios, proventos ou pensão do idoso, bem como qualquer outro documento com objetivo de assegurar recebimento ou ressarcimento de dívida:

Pena - detenção de 6 (seis) meses a 2 (dois) anos e multa.

9 HC 0026137-97.2013.4.01.0000/RO. 


\subsection{Dos depoimentos dos índios nos inquéritos policiais e nas audiências judiciais.}

Muitos foram os índios ouvidos nos inquéritos e nas audiências de instrução, de etnias diversas, moradores de aldeias distantes umas das outras e de graus distintos de interação com a sociedade envolvente, sendo que alguns deles foram ouvidos na língua materna, a partir de tradutor. Destacamos os depoimentos mais significativos, ressaltando que não houve depoimento consideravelmente divergente dos aqui retratados.

Indígena Wari', professor na Aldeia Laje Velho, disse que assinou procuração ao comerciante para movimentar sua conta bancária, que seria uma garantia de pagamento e que não concorda com tal fato, pois os nãoíndios podem pagar ao final do mês enquanto que os indígenas são obrigados a deixar o cartão como garantia de pagamento. Falou que faz compras e costuma pegar dinheiro emprestado com o comerciante e que os produtos e valores não são discriminados, razão pela qual não sabia se os valores estariam corretos; relatou que comprou uma peneira e pagou quinze reais e depois viu a mesma peneira noutro comércio por dez reais.

Indígena de uma aldeia com acesso terrestre disse que assinou a procuração para o comerciante movimentar sua conta bancária e que apenas era lançado o valor das compras, sem discriminação dos produtos ou valores. Falou não saber se os valores estavam corretos, no entanto soube dizer qual o valor que o comerciante lhe cobrara há cerca de três meses por fardos de açúcar e de arroz.

Índio da etnia Makurap, morador da Baía da Coca, agente indígena de saneamento, ouvido como vítima, disse conhecer o comerciante e que se sentia à vontade em falar na frente dele. Disse que escolheu o mercado do réu e não outro porque na época ganhava pouco, precisava das coisas, de combustível para o motor e como lá vendia a crédito, foi e deixou o cartão, visto que ia à cidade apenas a cada três meses. O comerciante retirava o dinheiro e entregava as mercadorias. Falou que o réu lhe dava dinheiro para comprar roupas, panelas, calçados e combustíveis noutros lugares e que sabia quanto ficava devendo. Em seguida, ao dizer que o comerciante lhe emprestava 
dinheiro, sem cobrar nada a mais por isso, concluiu que isso ocorria em nome da amizade que tinham. Falou que a mãe do comerciante também lhe emprestou dinheiro e que tinha muita amizade com ela. Após a Polícia Federal ter apreendido seu cartão, o indígena declarou que passou a retirar o dinheiro e comprar em outros lugares, sem, no entanto, deixar de comprar coisas no mercado do réu. Concluiu que não saia ganhando e nem perdendo na relação comercial.

Índio da etnia Kanoé, servidor da Funai, da aldeia Ricardo Franco, Terra Indígena Guaporé, disse que manteve negócios com o réu por cerca de dez anos, que fez uma procuração e deixou com ele, por conta da filha que fazia faculdade na Bolívia, que precisava de dinheiro todo mês, sendo que ele não podia ir à cidade todo mês. A cada 90 dias, "descia" à cidade para ajustar a conta. Buscava mercadoria e às vezes sobrava dinheiro, com o que ia a outras lojas comprar calçados, roupas. Conhecia a mãe do comerciante, que era sua amiga antiga e foi através dela que estabeleceu o comércio. Não olhava o preço das coisas em outros lugares, segundo ele "porque comprava do réu". Às vezes mandava um bilhete para ele enviar o que precisava, às vezes, dinheiro emprestado. Disse que cabia ao comerciante controlar os preços, que ele próprio não tinha condições de verificar. Confiava no réu porque ele era seu procurador, Ihe emprestava dinheiro. Que não sabe se foi enganado, mas acha que nada perdeu. Disse que parou de comprar por causa da intervenção policial, mas ainda considerava que o comerciante era seu amigo e se pudesse, voltaria a comprar lá.

Índio Wari' do rio Pakaas Novos, com um pouco de dificuldade em compreender a língua portuguesa, ouvido na própria língua por intérprete também Wari', disse que naquele tempo dos fatos, quando deixou o cartão, não sabia ainda usar o terminal eletrônico, mas que naquele momento já sabia. Falou que em outros tempos havia uma servidora da Funai que ajudava aos índios a lidarem com as coisas que envolvem bancos. Perguntado pelo intérprete sobre o preço, o valor das coisas, disse não saber.

Indígena Wari', também de aldeia na região do Pakaas Novos, disse que deixou o cartão do bolsa-família, para assim poder ir lá "pegar as coisas". Ao 
ser perguntada sobre se sabia o valor dos produtos, quanto valia o arroz, 0 açúcar e outros produtos, disse não saber. Falou que o comerciante somava e dizia "seu rancho custa 200 reais". Perguntada, lembrou e declarou sem titubear tudo que havia comprado na última vez que esteve no comércio do réu. Relatou que perguntava unicamente se o dinheiro dava para aquelas coisas que precisava. Então, o comerciante dizia o que poderia ser pego e em quais quantidades. Disse que achava as coisas caras, mas que suas filhas precisavam daqueles produtos e não tinha dinheiro para comprá-las, que só no comércio do réu podia pegar as coisas deixando o cartão e que foi ela quem procurou o réu, que foi ela quem quis deixar o cartão para o réu.

Indígena idoso, possivelmente tendo primeiro contato com os brancos já em vida adulta, ouvido na língua txapakura, com intérprete, disse que entregou o cartão de aposentadoria no mercado. Perguntado se compreendia a noção de tempo ocidental, para que respondesse por quanto tempo deixou o cartão lá, soube dizer apenas que foi por muito tempo. Reclamou que o comerciante não the deu dinheiro para o frete/transporte, que deu só em mantimentos. Perguntado sobre o valor das coisas, sobre o porquê a aposentadoria dar aquele tanto de mercadoria, disse que o comerciante autorizou pegar aquilo de mercadoria com o valor que veio no cartão, que não sabe o valor total do dinheiro ou o valor das coisas, das mercadorias. Perguntado se hoje ele sabe quanto vem de dinheiro, disse que sabe, respondendo que são 600 reais e que retira o dinheiro através do seu filho, vai comprar as mercadorias, paga o frete e retorna à aldeia.

\subsection{Depoimento do Coordenador da Funai}

O coordenador da Funai de Guajará-Mirim à época dos fatos, ouvido no processo judicial, disse que muitos índios reclamaram da apreensão dos seus cartões, bem como por serem implicados em questões jurídicas, com a polícia, leis, justiça e por isso ficaram alarmados. Disse que são os índios que, quando ainda não saiu seu benefício mensal e precisam de gêneros de primeira necessidade, procuram os comerciantes. Disse que reclamam à FUNAI apenas quando têm algum problema nos negócios com o comerciante, quando já 
houve algum desacerto. Disse que na negociação os valores dos produtos não são informados, individualizados. Disse que os índios não têm noção básica de matemática e da questão do tempo do modo que nós temos.

\subsection{Interrogatório de um comerciante réu}

O comerciante denunciado referiu que em razão da amizade que tinha com os professores índios, como eles costumavam demorar meses para receber seus salários, começou a dar-lhes crédito. Declarou que o costume era vender-Ihes sempre a mesma quantidade, que, assim, o valor era sempre o mesmo e que, quando dava valor maior, explicava qual o produto que tivera o preço aumentado. Mencionou que alguns índios ficaram com dívidas, nunca pagas. Disse que tem um comerciante que contratou um índio para fazer a intermediação com os demais parentes e ir ao banco sacar o dinheiro. Falou que deixou de fazer tal tipo de negócio e passou a vender a dinheiro por causa do problema judicial. ${ }^{10}$ Ao ser perguntado sobre por que professores, que sabem sacar dinheiro em banco, deixavam-Ihe o cartão bancário, respondeu que os professores the disseram que não gostam da burocracia dos brancos, a qual nunca entenderam e que não gostam de esperar pelo dia que vem o dinheiro. Neste momento da audiência, o juiz Ihe perguntou se ele considerava que os índios são "inocentes", que podem ser induzidos em erro e se são aculturados, ao que o comerciante respondeu que não são passíveis de serem enganados e que sim, são aculturados.

Após a realização da última audiência de um dos processos, o comerciante denunciado peticionou nos autos afirmando que ainda mantinha relações negociais com os índios, tendo um caderno individualizado para cada um, em que anotava o total das compras realizadas, sendo assinado ao final, sem a discriminação de cada item vendido, apenas anotando o total e a data da compra.

10 Importante referir que em depoimento prestado à Polícia, quatro anos após esse, abaixo mencionado, declarou que seu negócio encerrou as atividades por conta do impedimento da continuação da sistemática de venda aos índios. 
Declarou que mudou o sistema de cobrança, não mais com retenção de cartões, mas pela autorização de débito automático e que a continuidade de tais avenças refutariam a quebra de confiança que os índios teriam dito que ocorreu após a publicação das medidas policiais e judiciais sobre o caso. A sistemática implantada consistiria na autorização de débito em suas contas, feitas pelos índios junto aos bancos, basicamente a CEF. O comerciante acusado disse ao final de cada mês apresenta um relatório das vendas efetuadas, que são pagas pelo banco. O comerciante afirmou no processo que as supostas vítimas seguiam comerciando com ele, e que, como pequeno comerciante, não poderia prescindir dessa clientela. Tais fatos, segundo ele, denotariam que jamais os índios sentiram-se vilipendiados, havendo recíproca relação de confiança que ainda era mantida. Para comprovar o que falou, juntou documentos e vídeos - gravados sem autorização dos envolvidos mostrando suas conversas atuais (ao tempo do interrogatório) com alguns índios em seu comércio.

\subsection{Das conclusões do MPF e da Justiça Federal nas alegações finais e nas sentenças}

Em alegações finais, ou seja, após toda a instrução dos processos, análise das provas, oitiva dos índios como testemunhas e vítimas, o MPF pediu as condenações dos comerciantes nos crimes que lhes foram imputados. $O$ MPF concluiu, em síntese, que houve as retenções dos cartões e que restaram provados os ardis usados em prejuízo dos indígenas, bem como as vantagens ilícitas obtidas. Entendeu que as declarações dos índios dizendo, em alguns casos, que viram preços menores em outros mercados ou que o valor cobrado a título de juros em certos empréstimos, configuraram abuso. Entendeu, por fim, que houve aproveitamento da peculiar necessidade que aflige os indígenas e que as questões culturais exacerbaram a hipossuficiência dos índios.

As sentenças, em ambos os processos, foram muito parecidas na fundamentação e na conclusão. Os réus foram absolvidos das imputações dos estelionatos e condenados a seis meses de detenção e 10 dias-multa, cada um, pela retenção dos cartões dos idosos. 
O juiz, que foi o mesmo em ambos os processos, entendeu que ficou evidente a utilização de práticas deploráveis e abusivas, que tolheram a capacidade dos índios administrarem seus próprios recursos e adquirirem suas compras em outros estabelecimentos comerciais, com violação de normas consumeristas e dever de boa-fé objetiva, com exploração de consumidores hipossuficientes. No entanto, entendeu que não houve prova suficiente da utilização de exasperação de preços e utilização de contabilidade fraudulenta principalmente porque houve o extravio dos cadernos contábeis apreendidos pela PF nos estabelecimentos. Ou seja, absolvição se deu pelo extravio dos cadernos de anotações das contas dos índios, que seriam o corpo de delito, a materialidade da acusação. $O$ juiz entendeu que as provas orais apontadas pelo MPF para pedir condenação, que falavam em preços abusivos, não bastavam para tal, visto que haveria divergências dos índios quanto a aspectos cruciais, tendo boa parte deles dito que os preços cobrados seriam justos.

Em um dos processos, havia nos autos anotações de contas referentes a alguns índios, apreendidas no estabelecimento comercial. Em análise detalhada, o juiz refutou matematicamente a versão da PF, corroborada pelo MPF quando do oferecimento da denúncia. Por tal análise, por exemplo, surgiu outra explicação para a versão das sandálias que teriam custado 45 reais, sendo que o preço de mercado seria de 15 reais, fato usado como símbolo do abuso pelo Delegado no inquérito policial. O juiz verificou que, ao lado da anotação das sandálias, havia a anotação ilegível de algum outro produto, que não poderia ser ignorada. Essa mesma anotação existia em outras contas, com valor de $\mathrm{R} \$ 30,00$. Assim, como o valor legível era 45 reais, restou crível que foi cobrado 15 reais pelas sandálias.

Em fevereiro de 2018, quanto a um dos processos, o MPF apelou ao TRF da $1^{\text {a }}$ Região, buscando reformar a sentença para obter a condenação do réu pelos crimes de estelionato praticados contra os índios. O comerciante também recorreu de sua condenação pela retenção do cartão de uma indígena idosa, buscando a absolvição também desse delito. Quanto ao segundo processo, não houve recurso do MPF e nem do réu, transitando em julgado a sentença que condenou o comerciante pelo crime de retenção dos cartões dos 
indígenas idosos. Após, o juiz extinguiu a punibilidade do réu condenado, pela incidência da prescrição da pretensão punitiva.

Ainda há um inquérito policial ${ }^{11} \mathrm{em}$ andamento para investigar criminalmente a prática já costumeira em Guajará-Mirim, de venda aos índios mediante a retenção de seus cartões. Um dos comerciantes já denunciados, ouvido novamente pela PF em dezembro de 2017, disse que após ter sido preso e terem apreendidos os cartões dos índios, teve de fechar a empresa porque o movimento caiu bruscamente. Outra comerciante, ouvida em novembro de 2017 , disse que negocia com índios em sistema de trocas, em que eles entregam peixes, mandioca e farinha em troca de gêneros alimentícios e produtos de higiene pessoal. Negou reter cartões. No entanto, outro comerciante disse que esse comércio também teria tal prática.

Por fim, a Polícia Federal questionou a Funai a respeito das medidas que estão sendo adotadas para inibir tal prática. Não houve resposta.

\section{O INQUÉRITO CIVIL}

O inquérito civil ${ }^{12}$ foi instaurado, por um dos autores deste artigo, imediatamente após a primeira audiência do processo criminal em que os indígenas foram ouvidos.

O que tínhamos até então era o tratamento do problema unicamente através do Direito Penal, com a narrativa da criminalização das condutas dos comerciantes e vitimização dos índios. No entanto, conforme o conhecimento do caso foi aumentando, principalmente pelos depoimentos dos índios, evidenciou-se que havia algo mais complexo como pano de fundo, o que requeria maior compreensão e adoção, pelo MPF, de medidas de outra ordem, fora do estrito processo penal, que se limita à aplicação da lei penal aos fatos postos nos processos criminais. Assim, o inquérito civil foi instaurado com o objetivo explícito da busca de soluções para os problemas relativos ao uso de cartões de benefícios assistenciais e previdenciários por indígenas de Guajará- 
Mirim e Nova Mamoré, para que os valores a que tem direito fossem efetivamente revertidos em seu favor.

A FUNAI, instada pelo MPF a manifestar-se sobre a situação, disse que seus funcionários antigos atestaram que a prática vinha de longa data, que era recorrente e muito difícil de ser combatida, tendo em vista que muitas investidas já haviam sido feitas nesse sentido e que os feitos são temporários, com recorrência dos mesmos índios nos mesmos comércios. Disse que não tem instrumentos eficazes de combate a tais procedimentos e como interferir nas relações de compra e venda dos indígenas, mas que algumas vezes seus servidores fizeram comparativos de preços, indicando aos índios preços mais vantajosos em outros estabelecimentos, no entanto, sem sucesso.

Parecer antropológico produzido no inquérito concluiu, em apertada síntese, que o caso concreto evidenciou que os indígenas não compreendem bem os fatos envolvidos nesse tipo de negociação, seja pela dificuldade da língua, seja por possuírem concepções de mundo distintas. Discorreu sobre lacunas que dificultam ou anulam a efetividade de direitos, num cenário paradoxal marcado por políticas públicas universalizantes contrapostas às especificidades socioculturais dos povos indígenas. A Antropóloga disse ser evidente a necessidade dos indígenas cuidarem dos seus interesses, mas que há fatores que impedem a plenitude dessas responsabilidades, tais como a língua e o estranhamento com práticas que são da sociedade envolvente. Sugeriu medidas como a realização de audiências públicas para esclarecimentos aos indígenas, comerciantes locais e gestores públicos; a ampliação de mecanismos de informação às comunidades indígenas, com formulação de cartazes e cartilhas nas línguas maternas; recomendação aos bancos para que não autorizem saques sem a presença do indígena titular do cartão e ida de funcionário da CEF às comunidades para realizar os pagamentos. Por fim, sugeriu ao Procurador da República a propositura de ações que permitam a manutenção dos índios nos programas sociais sem que sejam vítimas de pessoas mal-intencionadas e que devem ser consideradas as suas especificidades étnicas e culturais. 
O MPF buscou junto aos órgãos governamentais o número de identificação de pessoas beneficiárias de programa bolsa-família em GuajaráMirim, identificando que mais da metade da população indígena local está direta ou indiretamente vinculada apenas ao programa bolsa-família. Em março de 2018, o MPF oficiou à Funai para que elaborasse projeto com campanha educativa para esclarecer os índios sobre o procedimento correto para 0 recebimento de seus benefícios e sobre a ilicitude da retenção de seus cartões magnéticos por terceiros, o que até agosto de 2019 ainda não havia ocorrido.

Foi determinada, no Inquérito Civil, diligência que foi realizada em abril de 2018, por servidor do MPF, cujo objetivo era de identificar locais que ainda realizariam a prática de retenção de cartões, buscando informações com indígenas. O servidor relatou que a diligência não foi satisfatória, vez que predominaria entre os índios a "lei do silêncio", já que não estavam dispostos a falar sobre o assunto.

Em março de 2019, no Inquérito Civil, a Procuradora da República atuante ressaltou, uma vez mais, que a prática de retenção de cartões magnéticos de indígenas por comerciantes é antiga e de difícil solução. Citou, como fatores que estimulam a situação, as barreiras enfrentadas pelos indígenas para os saques dos valores a que tem direito, bem como a facilidade promovida pelos comerciantes ao fornecer produtos imediatamente, ainda que a preços distorcidos se comparados àqueles usualmente praticados. Por conta disso, concluiu ser necessária a adoção de medidas de cunho educacional visando à conscientização dos indígenas sobre os prejuízos que tem suportado ao fornecerem seus cartões magnéticos a terceiros, bem como, a respeito da ilicitude da conduta praticada pelos comerciantes. Determinou diligências para identificar onde está o maior contingente populacional que recebe valores decorrentes de programas ou benefícios sociais para realizar ações educativas. Em seguida, oficiou à Funai para que elabore projeto destinado à promoção de campanha educativa com o fim de esclarecer eventuais dúvidas existentes pelos indígenas quanto ao procedimento correto para o recebimento de seus benefícios (assistenciais ou previdenciários), e, ainda, para orientá-los a 
respeito da ilicitude consistente na retenção e seus cartões magnéticos por terceiros.

O Inquérito Civil ainda está andamento, aguardando a realização da medida educacional acima indicada como medida positiva. A situação em si, as práticas, os problemas, as forças econômicas vigentes no uso de cartões de benefícios sociais pelas populações indígenas de Guajará-Mirim, ao que tudo indica, seguem intactas, havendo notícias no Inquérito Civil que tais práticas se dão também com populações ribeirinhas locais.

\section{A REGIÃO DE GUAJARÁ-MIRIM: CONTEXTO HISTÓRICO, GEOGRÁFICO E SOCIAL. RELAÇÕES ENTRE OS GRUPOS INDÍGENAS E A SOCIEDADE ENVOLVENTE.}

Guajará-Mirim, situada à margem direita do Rio Mamoré, fronteira boliviana, segundo maior município em extensão territorial do Estado de Rondônia, possui hoje cerca de metade da população indígena do Estado, segundo dados da Secretaria Especial de Saúde Indígena do Ministério da Saúde, que indicavam, em 2010, 11.130 indígenas no Estado. ${ }^{13}$ Há, em Guajará-Mirim mais de uma dezena de grupos étnicos em cerca de 30 aldeias indígenas, sendo a maioria delas situada às margens dos Rios Pakaas Novos, Mamoré e Guaporé.

Apesar das grandiosas contribuições de Curt Nimuendajú, Alfred Métraux, Claude Lévi-Straus e da Comissão Rondon, relatadas por Mauro Leonel na Etnodicéia Uruéu-Au-Au ${ }^{14}$, a que acrescento as narrativas e registros de Franz Caspar ${ }^{15}$, o mapeamento etnológico dessa região ainda contém muitas lacunas. Nimuendaju realizou trabalho monumental ao situar em mapas, confeccionados em 1943 e 1944, os grupos indígenas brasileiros. Neles, há

13 BRASIL. Ministério da Saúde. Fundação Nacional de Saúde. Disponível em: $<$ http://sis.funasa.gov.br/transparenciapublica/siasiweb/Layout/quantitativode pessoas2010.asp>.

14 LEONEL, Mauro. Etnodicéia Uruéu-Au-Au: O Endocolonialismo e os ìndios no Centro de Rondônia: O Direito à Diferença e à Preservação Ambiental. São Paulo: Editora da Universidade de São Paulo/Instituto de Antropologia e Meio Ambiente/Fapesp, 1995.

15 CASPAR, Franz. Tupari: Entre os Índios, nas Florestas Brasileiras. Edições Melhoramentos, São Paulo. 
descrição de vinte povos vivendo nas margens direita e esquerda do Rio Guaporé, apenas pertencentes a grupos falantes da língua Txapakura. Maior parte deles hoje está extinta. Soares-Pinto ${ }^{16}$ menciona que há os Makurap, Wajuru e Tupari, de língua tupi-tupari e os Aruá e Massacá, de língua tupimondé. E há diversas línguas isoladas, como Kanoe e Djeoromitxi. ${ }^{17}$

Fato é que na atualidade há grande diversidade de etnias indígenas na região de Guajará-Mirim, o que já havia sido identificado por Lévi-Strauss, no Handbook of South Americans Indians ${ }^{18}$, que retrata que as sociedades indígenas da margem direita do Guaporé, caracterizadas pela heterogeneidade linguística. A afirmação toma por base o fato da margem direita desse rio abrigar povos indígenas das famílias Txapakura, Tupi, Karib e Nambikwra e a margem esquerda, boliviana, abrigar a área cultural Mojo-Chiquitos, que se estende até os Andes.

A região concentra grande variedade de povos indígenas também em consequência dos projetos de colonização de Rondônia, fronteira pioneira na Amazônia Brasileira, impulsionada por causas econômicas, como exploração das madeiras nobres, látex, ouro, diamantes e cassiterita, que foram intensificadas pelos governos militares nos anos 70 e 80 do século passado, inclusive com apoio do Banco Mundial, pelo Programa Integrado de Desenvolvimento do Noroeste do Brasil (Polonoroeste), numa geopolítica que visava à ocupação de um suposto vazio demográfico, que, com apoio do SPI e da Funai, removeu os índios que sobreviveram às invasões de suas terras ancestrais para aldeias na Região de Guajará-Mirim, principalmente para a Terra Indígena Guaporé ${ }^{19}$, local pouco cobiçado pelos colonizadores, dado seu isolamento geográfico e a baixa fertilidade de suas terras. Exemplos desses índios deportados ou foragidos são os Kanoes, Makuraps, Djeoromitxis,

16 SOARES-PINTO, Nicole. Entre as Teias do Marico: parentes e pajés djeoromitxi. Tese (Doutorado em Antropologia Social) - Programa de Pós-graduação em Antropologia Social da Universidade de Brasília. Brasília, 2014.

17 Linguistas do Museu Goeldi defendem que a língua Djeoromitxi pertence ao tronco macrojê.

18 LEVI-STRAUSS, Claude. Tribes os the Right Bank of the Guaporé River. In: STEWARD, Julian (org.) Hanndbook of South American Indians. v. 3, Washington: Smithsonian Institution. Bulletin v. 143, p. 371-379, 1948.

19 MINDLIN, Betty. Moqueca de Maridos: Mitos Eróticos Indígenas. 1. ed. São Paulo/Rio de Janeiro: Paz e terra, 2014. 
Arikapus, Arowas e Tuparis, hoje vivendo à margem direita do Guaporé, alguns deles arrolados e ouvidos como vítimas ou testemunhas no presente caso de supostos abusos econômicos.

A construção da estrada de ferro Madeira-Mamoré, no início do século XX, ligando a atual cidade de Porto Velho e Guajará-Mirim, deu início a outro eixo de invasões, impulsionadas pelos ciclos da borracha, que também dizimaram boa parte dos povos indígenas, pela invasão de suas terras e propagação de doenças contagiosas desconhecidas, para as quais não tinham anticorpos.

Os Waris, grande nação indígena, falantes da língua Txapakura, com cerca de uma dezena de subetnias - maior parte dos índios envolvidos no caso das retenções de cartões magnéticos em estudo - apesar de suas terras terem sido atravessadas nas bordas pela ferrovia, mantiveram-se isolados de contato com os brancos até a segunda metade do século $X X$, quando suas áreas tradicionais, que estavam nos arredores da zona urbana de Guajará-Mirim, passaram a ser sistematicamente invadidas. Índios guerreiros, resistiram muito.

Vilaça ${ }^{20}$, relatou que a situação de conflito entre índios e brancos agravou-se na região de Guajará-Mirim a partir da década de 1940, pela demanda de borracha da II Guerra Mundial, com a chegada de uma nova leva de seringueiros. Em 1945 iniciaram-se os projetos agrícolas. Nos anos 1950, as áreas dos rios Laje e Ribeirão foram invadidas por prospectores de cassiterita. Os Wari' percebiam que os brancos estavam chegando muito perto de suas aldeias e os atacavam. Os brancos revidavam, organizando expedições punitivas, em que aldeias eram invadidas ao amanhecer por homens armados com metralhadoras, matando muitos índios, inclusive crianças ou idosos.

Assim, não lhes restou outra alternativa à rendição e à vida nos postos de atração a partir dos anos 60 do século passado. Aparecida Vilaça, em sua obra "Quem Somos Nós - Os Wari" Encontram os Brancos"21, faz uma leitura

20 VILAÇA, Aparecida. Quem Somos Nós: os Wari' Encontram os Brancos. Rio de Janeiro: Editora UFRJ, 2006. p. 347.

21 VILAÇA, Aparecida. Quem Somos Nós: os Wari' Encontram os Brancos. Rio de Janeiro: Editora UFRJ, 2006. p. 485. 
interessante, dizendo que os Wari', nos momentos derradeiros do contato, procuraram os brancos antes de tudo em movimento em direção à sociedade Wari', à vida social, que havia sido desorganizada e mesmo interrompida com a invasão.

Mindlin, em Tuparis e Tarupás (p. 16-17), assim como em Moqueca de Maridos $^{22}$, relata que apesar de terem mais de 50 anos de contato, os Tupari, Makurap, Wajuru, Aruá, Djeoromitxi, Kanoe e outros viveram bastante isolados no mato e nos seringais até meados dos anos 80 do século passado. Muitos, em especial as mulheres, mal falavam o português e não conheciam a cidade, vivendo em regime de subsistência, quase sem dinheiro, com fartura de peixes e caça. Como já mencionado, questão essencial para compreensão da dinâmica de uso dos cartões de benefícios sociais, a maior parte das aldeias tem acesso unicamente por rios e são distantes da cidade, normalmente a mais de um dia de viagem.

A partir de meados dos anos 80 , a violência da região voltou a pressionar esses povos, só que agora, não tanto as atrocidades explícitas de outrora, mas de modo mais velado, sistemático e progressivo, pelos projetos de "ocupação" da Amazônia pelos governos militares, que levaram centenas de milhares de colonos, principalmente do Sul do Brasil para o Estado de Rondônia, cujos projetos de assentamento oficiais se deram sobre terras indígenas e pela investida sobre a riqueza daquelas terras que lhes foram demarcadas - ínfimas diante das vastas regiões que até a pouco tempo ocupavam -, em especial a invasão por madeireiros e garimpeiros, contexto detalhadamente descrito pela pesquisa de Leonel $(1995)^{23}$.

\section{DAS ESTRUTURAS E PRÁTICAS SOCIOECONÔMICAS INDÍGENAS E SUA INSERÇÃO NA ECONOMIA DA SOCIEDADE OCIDENTAL}

22 MINDLIN, Betty. Moqueca de Maridos: Mitos Eróticos Indígenas. 1. ed. São Paulo/Rio de Janeiro: Paz e terra, 2014. p. 296.

23 LEONEL, Mauro. Etnodiceia Uruéu-au-au: O Endocolonialismo e os Índios no Centro de Rondônia. O Direito à Diferença e á Preservação Ambiental. São Paulo: Editora da Universidade de São Paulo/Instituto de Antropologia e Meio Ambiente/Fapesp, 1995. 
A vida econômica é parte da cultura. Uma não existe sem a outra. Os grupos humanos, em qualquer tempo e lugar, adotam práticas econômicas, usam de engenhosidade e inteligência que visam aos mesmos fins, de satisfação das necessidades humanas básicas. Jamais se observou um povo que não possua nenhuma estrutura social e não esteja sujeito a condições econômicas ${ }^{24}$.

Ao contrário do que muitos imaginam, havia, antes da chegada dos europeus às Américas, sistemas econômicos complexos em pleno funcionamento, tanto no que tange à produção e cultivo, como de redes de comércio baseadas nas trocas. As populações indígenas pré-colombianas, conforme os estudos arqueológicos vêm revelando ${ }^{25}$, eram muitos maiores do que se supunha, o que conduz a contatos entre os grupos, com trocas de tecnologias e costumes.

Lévi-Strauss $^{26}$ expôs que cada civilização tende a superestimar a orientação objetiva do seu pensamento e que cometemos o erro de ver o selvagem como exclusivamente governado por suas necessidades orgânicas. No entanto, todos os grupos humanos, atuais e passados, tem linguagem, artes, técnicas, conhecimentos, crenças e economia.

As técnicas e conhecimentos indígenas costumam ser vistas com desdém por não interessarem ou não ser compreendidas pelo observador. É uma visão ingênua resultante de uma total ignorância da complexidade e diversidade das operações implicadas nas técnicas mais elementares, como fabricar um instrumento de pedra que funcione, elaborar um vaso de cerâmica, produzir um arco, zarabatana ou bumerangue, todas tarefas compostas de operações numerosas e complexas ${ }^{27}$.

Caldeira $^{28}$, em suas pesquisas sobre sistemas produtivos dos povos sem escrita, observou fato que deve ser conectado com o que diz Lévi-Strauss, que

24 BOAS, Franz. A mente do ser humano primitivo. 2. Ed. Petrópolis, RJ. Vozes, 2011. p. 134. 25 MIRANDA, Evaristo Eduardo de. Quando o Amazonas corria para o Pacífico. 2. ed. Petrópolis/RJ: Vozes, 2007. p. 71-72.

26 LÉVI-STRAUUS, Claude. (2012). O Pensamento Selvagem. 12. ed. Campinas, SP: Papirus, 2012.

27 LÉVI-STRAUSS, Claude. Antropologia Estrutural Dois. São Paulo: Cosac-Naify, 2013. p. 383-385.

28 CALDEIRA, Jorge. História da Riqueza no Brasil. Rio de Janeiro: Estação Brasil, 2017. 
alertou sobre a subjetividade de concepções de civilizações desenvolvidas ou atrasadas: em três ou quatro horas diárias de trabalho os moradores das aldeias tupis produziam não apenas o necessário para sobreviver, mas o suficiente para manterem estoques de segurança alimentar. Isso, numa época em que a fome era um flagelo na Europa. Desse modo, os Tupis voltavam todo esforço econômico para eficiência máxima da distribuição, para a igualdade social, não fazendo sentido trabalhar mais que o necessário à preservação do seu povo. No século XVI, observa Caldeira, enquanto os médicos europeus manipulavam algo como uma centena e meia de espécies vegetais, algumas populações indígenas na América trabalhavam cerca de 3 mil espécies, sendo que três quartos de todas as drogas medicinais de origem vegetal empregadas atualmente no mundo derivam desse conhecimento nativo.

Há de se considerar que esses povos não conheciam a escrita e tinham outros modos de conceber a contagem e a matemática. No entanto, a falta de escrita está longe de significar a inexistência de leis, pois todos os grupos viviam sob regras precisas de comportamento, dadas pelos costumes.

Fábio Mura ${ }^{29}$ pesquisou a organização econômica dos Guarani Kaiowa, constatando que todos os objetos, animais domésticos e até frações das roças tem proprietários individuais, com exceção da terra. Desde o nascimento, o indivíduo recebe em dom objetos que ficam na sua posse até que ele decida se e como transacioná-los. As crianças costumam ter patos, galinhas e outros animais domésticos e quando alcança aproximadamente seis anos, recebem um pequeno espaço, destinado ao plantio de sua roça particular, cujos produtos serão considerados sua propriedade.

Há desconhecimento sobre as grandes contribuições dos ameríndios à humanidade no que tange às atividades agrícolas. Como referimos ao longo da pesquisa, os indígenas americanos domesticaram inúmeras espécies vegetais (ao lado de algumas espécies animais), fazendo seleção, manejo e controlando pragas, utilizando-as para diversos fins. Podemos citar as batatas, o milho, a borracha, o tabaco, a coca (base da anestesia moderna), o amendoim, o cará,

29 MURA, Fábio. À procura do "Bom Viver": Território, tradição de conhecimento e ecologia doméstica entre os Kaiowa. v. 1 e 2. Rio de Janeiro: Universidade Federal do Rio de Janeiro Museu Nacional. Programa de Pós-graduação em Antropologia Social. 
o cacau, a baunilha, o tomate, o abacaxi, bananas, mamão, pimentas e pimentões, favas, algodão e - fato único na história da humanidade promoveram substâncias venenosas como a mandioca a alimento de base ${ }^{30}$. Os Kayapó introduzem 58 diferentes espécies por roça, com 17 variedades de mandioca e 33 de batata doce, inhame e taioba. Mesmo em regiões consideradas pobres em solo, com águas ácidas e poucos nutrientes, os índios acabaram conseguindo um alto aproveitamento, como no caso do Rio Negro, onde foram descritas 1.300 plantas utilizadas, entre outros fins, como venenos e remédios ${ }^{31}$.

A relação gradativa e constante com a sociedade envolvente, impulsionada pelo reconhecimento de direitos a partir da Constituição de 1988 inseriu os grupos indígenas da região de Guajará-Mirim no sistema econômico da sociedade ocidental, com o uso da moeda corrente e sistemas bancários, sem adequações quanto a alguns aspectos relativos às especificidades por serem grupos culturais diferenciados, que vivem em condições bem distintas da maior parte da população que tem os mesmos direitos. Cardoso de Oliveira $^{32}$ expõe que o sistema interétnico tem três níveis de operação, o econômico, o social e o político. Segundo ele, o nível econômico "se reveste de particular importância porque é nele que tem lugar os fenômenos mais determinantes do sistema interétnico".

Leão ${ }^{33}$, em seu Relatório Antropológico, ao tratar dos povos indígenas do Rio Guaporé em Rondônia, disse que "a dizimação, o contato indiscriminado e a inserção obrigatória na sociedade envolvente como mão de obra, não impediu que estes índios se reestruturassem política, social e economicamente".

Alguns fatores colaboraram para a rápida inserção dos índios de Guajará-Mirim no sistema econômico hegemônico. Os recursos naturais, de

30 LÉVI-STRAUSS, Claude. Antropologia estrutural dois. São Paulo: Cosac Naify, 2013. p. 373 31 LEONEL, Mauro. Bio-sociodiversidade: preservação e mercado. Disponível em: http://www.scielo.br/scielo.php?script=sci_arttext\&pid=S0103-40142000000100019. Consulta em 12 Set 2019.

32 OLIVEIRA, Roberto Cardoso de. Estudo de Áreas de Fricção Interétnica no Brasil. América Latina. Rio de Janeiro, ano 59, n. 3, 1962. p. 87.

33 SÁ LEÃO, Maria Auxiliadora. Relatório Antropológico de demarcação da Terra Indígena Rio Guaporé. FUNAI. 1985. 
que dependia sua subsistência desde que passaram a viver sedentários em áreas demarcadas foram sendo pressionados progressivamente pelo aumento das populações das cidades, pelas grandes usinas e obras de infraestrutura, pela agropecuária e pela caça e pesca no entorno de suas terras. Outro fator a ser considerado é a recuperação demográfica da população indígena, que havia sido drasticamente reduzida por ocasião do contato, só que agora sem acesso à significativa parte de suas roças tradicionais, com as terras pretas de índio, que ficaram fora das áreas demarcadas. Ainda, acrescente-se o fenômeno global do acelerado desenvolvimento tecnológico e do consumismo, que também atingem os grupos indígenas, criando-lhes necessidades e utilidades que dependem de recursos financeiros para satisfação.

Também, não se pode olvidar que alguns grupos de índios veem na posse de bens dos brancos a entrada na sociedade de consumo, como parte de sua lógica tradicional de significação da alteridade, como observa SoaresPinto $^{34}$ em resenha sobre os Xicrin-Mebêngôkre, situação que parece muito análoga à dos Wari'de Guajará-Mirim, que segundo Vilaça ${ }^{35}$ têm interesse em viver como brancos, sem, no entanto, com eles confundirem-se, numa espécie de metamorfose reversível. Tais situações vão além do simples interesse na posse de bens materiais mas encerram tais interesses.

Nesse contexto, com o incremento dos programas sociais no Brasil a partir da Constituição Federal de 1988, abrangendo, como relatado acima, parte significativa das populações indígenas, é que surge e se desenvolve a lógica econômica que permeia as relações ora estudadas. É necessário contextualizar o "problema" sob todos esses aspectos, sob pena de não os compreendermos com clareza e também não podermos vislumbrar como lidar com a situação.

\section{DA IMPORTÂNCIA DAS RELAÇÕES INTERPESSOAIS E DA CONFIANÇA PARA OS INDÍGENAS DE GUAJARÁ-MIRIM}

34 PINTO, Nicole Soares. Economia selvagem: ritual e mercadoria entre os XikrinMebêngôkre. Mana[online]. v. 14, n. 1, p. 249-252, 2008. Disponível em: <http://www.scielo.br/scielo.php?script=sci_arttext\&pid=S0104-93132008000100011>.

35 VILAÇA, Aparecida. Quem Somos Nós: os Wari' Encontram os Brancos. Rio de Janeiro: Editora UFRJ, 2006. p. 501. 
As relações de comércio intertribais verificadas por Malinowski no Kula, com base nas trocas intertribais que geram créditos sucessivos entre os parceiros, têm a confiança, a honra e moral como seus avais.

A confiança é a base por trás de todos os sistemas de coisas usadas como moedas. Como diz Harari36 a confiança é a matéria-prima com que todos os tipos de dinheiro são cunhados. O que cria essa confiança é uma complexa rede de relações políticas, sociais e econômicas de longo prazo. Os primeiros registros que se tem de "dinheiro" eram coisas que tinham valor intrínseco, como grãos de cevada para os sumérios, isso, até que as pessoas ganhassem confiança em algo simbólico. Hernan Cortés invadiu o desenvolvido Reino Asteca em 1519. Os nativos conheciam o ouro, usado para fazer joias e às vezes como moeda de troca. No entanto, os astecas usavam como moedas grãos de cacau ou rolos de tecido. Conclui Harari que o dinheiro é, consequentemente, um sistema de confiança mútua, e mais que isso, é o mais universal e mais eficiente sistema de confiança mútua já inventado.

O povo Wari", maior parte das "vítimas" envolvidas no caso em estudo, conforme já mencionado neste trabalho, foi pacificado nos anos 50 e 60 do século XX. Hoje, ainda se referem aos brancos como wijam, que significa "inimigo". Vilaça $(2018)^{37}$ refere que no seu período de convivência com os Wari" quando a convidavam para dançar diziam: "Mulher inimiga/branca, dançar!".Isso, por si só, já diz muito. Há uma natural desconfiança com as nossas intenções para com o seu povo, situação que pode mudar conforme demonstra-se, com ações, o merecimento de confiança.

Em determinada situação, quando ocorreram adoecimentos e mortes em número estatisticamente maior que o que vinha ocorrendo, já insatisfeitos com o estado geral dos serviços públicos de saúde, os índios disseram que estavam sendo assassinados pelos brancos, ou simplesmente deixados para morrer, já que partiam vivos das aldeias para o hospital e de lá só retornavam mortos. Tal

36 HARARI, Yuval Noah. Sapiens: Uma Breve História da Humanidade. 5. ed. Porto Alegre: L\&PM, 2015.

37 VILAÇA, Aparecida. Paletó e eu: memórias de meu pai indígena. 1. ed. São Paulo: Todavia, 2018. p. 41. 
situação, naquele momento, motivou a tomada da Casa de Saúde Indígena ${ }^{38}$, a fim de buscarem melhorias no quadro da saúde. Os fatos evidenciam que em níveis psicológicos a guerra que perdurou até os anos 60 do século passo ainda continua. Gilberto Freyre, em Casa-Grande \& Senzala ${ }^{39}$, ressalta a importância das tendências psicológicas ou psicofisiológicas a serem acrescentadas a um sentido puramente material e marxista dos fatos, indicando que atuam sobre as sociedades, bem como sobre os indivíduos, independente de pressão econômica, forças psicofisiológicas, ao lado das emoções de fome, sede, sexo. Forças essas de uma grande intensidade de repercussão.

Diante do ambiente que Ihes foi historicamente hostil até há pouco tempo, contata-se que nos depoimentos dos índios sobressaem as declarações que ressaltam e valorizam as relações de confiança e de amizade com os comerciantes, construídas também por parentes de ambos os lados. Percebese que valorizam mais a confiança na relação, que não os deixará sem os produtos básicos que necessitam, mesmo que não tenham recursos naquele momento, do que o preço dos bens. Um comerciante também declarou que faz tal tipo de negócio por ser amigo dos índios.

Em depoimento prestado na audiência relatada, indígena disse que não olhava o preço das coisas "porque comprava do réu" e que bastava lhe enviar um bilhete para receber o que precisava. Pode-se depreender, interpretar da seguinte forma: "Se compro dele, é porque tenho relação de confiança com ele, se tenho relação de confiança com ele, não preciso conferir o preço".

Não se pode olvidar que o significado da amizade e mesmo as bases da confiança são diversas entre os índios e os comerciantes.

\section{CONCLUSÃO}

38 SALDANHA, Dayanne. Protesto na Casai de Guajará encerra após negociações com indígenas. G1, 30 de janeiro de 2015. Disponível em: <http://g1.globo.com/ro/rondonia/noticia/2015/01/protesto-na-casai-de-guajara-encerra-aposnegociacoes-com-indigenas.html>.

39 FREYRE, Gilberto. Casa-Grande \& Senzala. 51. ed. São Paulo: Editora Global, 2015. 
Nas últimas duas décadas, decorrência da efetivação de normas constitucionais, do mesmo modo que ocorreu no Brasil todo, houve incremento de benefícios sociais e previdenciários concedidos aos indígenas. No entanto, vimos no caso relatado que não houve qualquer adaptação que atendesse às necessidades dos grupos étnicos diferenciados. Para acesso aos benefícios, o governo, pelos agentes bancários, forneceu cartões magnéticos para retirada de valores em agências ou terminais bancários. O modelo, além de pragmaticamente inadequado, vai de encontro a direitos constitucionais dos índios à sua organização social, tradições e costumes e pela Convenção 169 da OIT, que determina que medidas legislativas ou administrativas que possam afetar diretamente os povos indígenas necessitam de sua consulta livre, prévia e informada antes da implementação. ${ }^{40}$

No imaginário coletivo a figura do índio ainda transita entre o romantismo do bom selvagem, que evoca a ingenuidade e pureza e a figura do bárbaro preguiçoso. No processo judicial consta manifestação simbólica a respeito dos acontecimentos que diz ser o índio "hipossuficiente por ser índio". A prática comercial foi tida como deplorável e abusiva. Debate-se sobre aculturação. Há, seguramente, preconceitos e estereótipos, ainda que inconscientes, nessas concepções, que veem o índio como próximo à natureza e longe da cultura, concebendo-o com incapacidades de inteligentemente compreender e tomar as melhores decisões.

Notou-se, pelos depoimentos dos índios e pela análise global dos fatos, que se evidencia uma relação vantajosa para ambas as partes, dadas as circunstâncias peculiares e difíceis em que se encontram as populações indígenas de Guajará-Mirim para terem acesso aos seus direitos, dada a inadequação evidente do Programa Bolsa-Família, que concede pouco mais de cem reais por família ao mês, sendo que boa parte dos indígenas teria de gastar, em transporte para deslocamento até um terminal bancário, valores três ou quatro vezes maiores que o do benefício .

40 Art. $6^{\circ}$ Ao aplicar as disposições da presente Convenção, os governos deverão:

a) consultar os povos interessados, mediante procedimentos apropriados e, particularmente, através de suas instituições representativas, cada vez que sejam previstas medidas legislativas ou administrativas suscetíveis de afetá-los diretamente; 
Os depoimentos dos indígenas e dos demais atores envolvidos, denotam que os indígenas não têm uma visão puramente economicista, com foco no valor dos bens. As relações interpessoais e a confiança construída ao longo do tempo são muito mais importantes que o estrito valor mensal do benefício, pois lhes garante a entrega efetiva dos produtos, além de outros serviços, a distâncias enormes, mediante o envio de um bilhete por terceira pessoa, tenham ou não crédito na conta de benefício naquele momento.

Quanto aos valores dos produtos, tidos como exacerbados, o que restou demonstrado é o ordinário em qualquer lugar do país. Mercados menores, que vendem a prazo, tendem a ter valores um pouco maiores que grandes mercados que vendem à vista. Situação típica do local, há de se considerar, como em qualquer cidade, que há despesas de transporte, que no caso em questão, são naturalmente elevadas. De qualquer modo, como dito, nitidamente, o foco dos indígenas não está na relação consumidor-mercadoria, ao que parece darem pouca importância, mas sim nas relações pessoais, numa situação que vai na contramão da tendência moderna, criticada por Bauman ${ }^{41}$, mas que talvez, por estar consolidada na sociedade ocidental, cause estranheza pela diferença de pensar, coisa típica do trato interétnico.

Como mencionado ao longo deste estudo, os índios são tão intelectualmente capazes quanto qualquer outra pessoa. Desconhecimento da língua, de costumes e do funcionamento de máquinas modernas, como terminais bancários, são dificuldades inerentes a qualquer ser humano

No aspecto criminal não se verificaram as elementares dos tipos penais imputados, como vantagem ilícita e prejuízo alheio mediante ardil ou fraude. Os envolvidos tinham plena ciência da relação que estabeleceram por vontade própria e que reputaram vantajosa.

O Chefe local da Funai declarou que são os índios que, quando ainda não está disponível seu benefício mensal e precisam de gêneros de primeira necessidade, procuram os comerciantes. Disse que reclamam à FUNAI apenas quando têm algum problema nos negócios com o comerciante, quando já houve algum desacerto. Ou seja, os indígenas, como demonstrado, têm plena

41 BAUMAN, Zygmunt. A Modernidade Líquida. Rio de Janeiro: Zahar, 2001. p. 23. 
noção sobre os contornos de suas relações comerciais, tanto que, ao perceberem algo que na sua visão não está certo ou que lhes deixa insatisfeitos, recorrem à Funai.

Significativo que apenas nos dois processos citados houve mais de duas centenas de supostas vítimas, grande parte mantendo a relação comercial por muitos anos. Isso, por si, indica não ser verossímil a narrativa do abuso fraudulento contra os índios, pois não seria logicamente possível enganar tantas pessoas por tanto tempo, considerando-se, também, que, dentre as supostas vítimas, havia professores e servidores públicos, com pleno conhecimento da língua e aspectos culturais da sociedade ocidental.

Quanto à retenção dos cartões, num primeiro olhar medida ilícita já que são cartões pessoais e intransferíveis, há de se considerar, pragmaticamente, que é o meio possível e livremente consentido para o sistema consolidado funcionar, visto que o dinheiro só é acessado na cidade, uma vez por mês, e os índios vivem, como dito, muito distantes da cidade. Não se pode esquecer que havia centenas de procurações dos índios para que eles pudessem movimentar suas contas bancárias, no que, poder-se-ia compreender estarem os cartões magnéticos inseridos. Tais circunstâncias indicam ausência de dolo na conduta de retenção dos cartões.

Ainda, no aspecto criminal, com o estudo de caso, entendo que mesmo que superada a questão da falta de elementares que impedem a adequação típica, ainda faltaria a potencial consciência da ilicitude, elemento da culpabilidade tipo penal $^{42}$, que diz só ser possível a punição do agente que, diante das condições fáticas em que estava inserido, tinha a possibilidade de compreender o caráter criminoso de sua conduta. Não se constata a consciência e vontade dos comerciantes direcionadas à realização de condutas criminosas. Veja-se, a respeito, o seguinte fato elucidativo: Um dos comerciantes denunciados, após ter sido preso e processado por crime, apresentou prova no processo no sentido de continuar a vender a crédito aos índios, mediante um novo sistema de débito em conta, no qual, ao invés do uso fato, se inevitável, isenta de pena; se evitável, poderá diminuí-la de um sexto a um terço. 
do cartão, informava de tempos em tempos os valores gastos pelos índios e o banco providenciava o débito nas suas contas, com o respectivo crédito na conta do comerciante.

Ora, o sistema apresentado pelo réu no processo, como prova da mudança do modo de conduzir os negócios com os índios para adequar-se à lei, não possui qualquer diferença substancial com aquele pelo qual ele foi denunciado, pois apenas retirou o uso do cartão mas seguiu usando os mesmos métodos de venda, cobrança e fixação aparentemente arbitrária de preços, o que evidencia a falta de consciência do caráter ilícito de sua conduta, pois apresentou esse novo sistema no processo em que é acusado de usar de ardis ou fraudes, como demonstração que estaria a atender aos requisitos da lei.

O Estado falhou e se omitiu ao implementar o Programa Bolsa-Família aos indígenas de Guajará-Mirim sem qualquer debate e consideração à realidade e às necessidades dos grupos étnicos diferenciados, em inobservância às normas jurídicas incidentes, acima mencionadas. E, falhou, uma vez mais, ao intervir unicamente através do Direito Penal, inadequado e ineficaz para tratar complexas relações.

\section{REFERÊNCIAS}

AYDON, Cyril. A História do Homem: uma introdução a 150 mil anos de história humana. Rio de Janeiro: Record, 2011.

BAUMAN, Zygmunt. A Modernidade Líquida. Rio de Janeiro: Zahar, 2001.

BOAS, Franz. A mente do ser humano primitivo. 2. Ed. Petrópolis, RJ. Vozes, 2011.

BRASIL. Código Penal. Decreto-lei n.2.848, de 7 de dezembro de 1940.

BRASIL. Constituição (1988). Constituição da República Federativa do Brasil. Brasília, DF: Senado Federal: Centro Gráfico, 1988.

BRASIL. Lei n. 10.741, de outubro de 2003. Dispõe sobre o Estatuto do Idoso e dá outras providências.

BRASIL. Ministério da Saúde. Fundação Nacional de Saúde. Disponível em: $<$ http://sis.funasa.gov.br/transparenciapublica/siasiweb/Layout/quantitativode pessoas2010.asp>. 
CALDEIRA, Jorge. História da Riqueza no Brasil. Rio de Janeiro: Estação Brasil, 2017.

CASPAR, Franz. Tupari: Entre os Índios, nas Florestas Brasileiras. São Paulo: Edições Melhoramentos.

CAVALLI-SFORZA, Luigi L. Genes, Povos e Línguas. São Paulo: Companhia das Letras, 2003. 296p.

CLASTRES, Pierre. A sociedade contra o Estado: pesquisas de antropologia política; tradução de Theo Santiago. Rio de Janeiro, F. Alves, 1978.

CUNHA, Manuela. O futuro da questão Indígena. Estudos Avançados, v. 8, n. 20, p. 121-136, 1994. Disponível em: $<w w w . s c i e l o . b r / p d f / e a / v 8 n 20 / v 8 n 20 a 16 . p d f>$.

FREYRE, Gilberto. Casa-Grande \& Senzala. 51. ed. São Paulo: Editora Global, 2015.

GRAY, John. Cachorros de Palha: reflexões sobre humanos e outros animais. 8a Edição. Rio de Janeiro: Record, 2013.

HARARI, Yuval Noah. Sapiens: Uma Breve História da Humanidade. 5. ed. Porto Alegre: L\&PM, 2015.

KOLBERT, Elizabeth. À Flor da Pele. National Geographic, abril 2018. p. 40.

LEONEL, Mauro. Bio-sociodiversidade: preservação e mercado. Disponível em: http://www.scielo.br/scielo.php?script=sci arttext\&pid=S010340142000000100019.

LEONEL, Mauro. Etnodicéia Uruéu-Au-Au: O Endocolonialismo e os ìndios no Centro de Rondônia, O Direito à Diferença e à Preservação Ambiental. São Paulo: Editora da Universidade de São Paulo/Instituto de Antropologia e Meio Ambiente/Fapesp, 1995.

LÉVI-STRAUSS, C. História de Lince. São Paulo: Editora Schwarcz, 1993.

LÉVI-STRAUSS, Claude. Antropologia Estrutural Dois. São Paulo: CosacNaify, 2013

LÉVI-STRAUSS, Claude. Mito e Significado. Lisboa - Portugal: Edições 70, março de 2007.

LEVI-STRAUSS, Claude. Tribes os the Right Bank of the Guaporé River. In: STEWARD, Julian (org.) Hanndbook of South American Indians. v. 3, Washington: Smithsonian Institution, 1948. Bulletin 143:371-379.

LÉVI-STRAUUS, Claude. O Pensamento Selvagem. 12. ed. Campinas, SP: Papirus, 2012. 
MALINOWSKI, Bronislaw. Argonautas do Pacífico Ocidental. São Paulo: Victor Civita, 1976.

MINDLIN, Betty. Moqueca de Maridos: Mitos Eróticos Indígenas. 1. ed. São Paulo/Rio de Janeiro: Paz e terra, 2014.

MIRANDA, Evaristo Eduardo de. Quando o Amazonas corria para o Pacífico. 2. ed. Petrópolis/RJ: Vozes, 2007.

MURA, Fábio. À procura do "Bom Viver": Território, tradição de conhecimento e ecologia doméstica entre os Kaiowa. v. 1 e 2. Rio de Janeiro: Universidade Federal do Rio de Janeiro - MUSEU NACIONAL. Programa de Pós-graduação em Antropologia Social.

OLIVEIRA, Roberto Cardoso de. Estudo de Áreas de Fricção Interétnica no Brasil. América Latina. Rio de Janeiro, ano 59, n. 3, 1962.

SÁ LEÃO, Maria Auxiliadora. Relatório Antropológico de demarcação da Terra Indígena Rio Guaporé. FUNAI, 1985.

SOARES-PINTO, Nicole. De coexistências: sobre a constituição de lugares djeoromitxi. Revista de @ntropologia da UFSCar, v. 9, n. 1, jan./jun. 2017. Disponível em: $<w w w . r a u . u f s c a r . b r / w p-$ content/uploads/2017/10/3_Nicole_Soares-Pinto.pdf>.

SOARES-PINTO, Nicole. Economia selvagem: ritual e mercadoria entre os Xikrin-Mebêngôkre. Mana[online]. v. 14, n. 1, p. 249-252, 2008. Disponível em: <http://www.scielo.br/scielo.php?script=sci_arttext\&pid=S010493132008000100011>.

SOARES-PINTO, Nicole. Entre as Teias do Marico: parentes e pajés djeoromitxi. Tese (Doutorado em Antropologia Social) - Programa de Pósgraduação em Antropologia Social da Universidade de Brasília. Brasília, 2014.

VILAÇA, Aparecida. Quem Somos Nós: os Wari' Encontram os Brancos. Rio de Janeiro: Editora UFRJ, 2006. 